\title{
Assessment of the efficiency of low level laser therapy in women with primary fibromyalgia syndrome: a randomized, placebo-controlled, double- blind study.
}

\section{Primer fibromiyalji sendromlu kadınlarda düşük enerji seviyeli lazer tedavisinin etkinliğinin değerlendirilmesi; randomize, placebo kontrollü, çift kör çalışma}

\author{
Gülbahar Ergün ${ }^{1}$, Ebru Atalar², Gülümser Aydın³ \\ ${ }^{1}$ Fiziksel Tıp ve Rehabilitasyon Kliniği, Fatsa Devlet Hastanesi, Ordu \\ ${ }^{2}$ Romatoloji kliniği, Ankara Şehir Hastanesi, Ankara \\ ${ }^{3}$ Fiziksel Tıp ve Rehabilitasyon Kliniğii, Yenimahalle Eğitim ve Araştırma Hastanesi, Ankara
}

Dergiye Ulaşma Tarihi:06.05.2020 Dergiye Kabul Tarihi:14.05.2020 Doi: 10.5505/aot.2020.65477

\section{ÖZET}

GİRIŞ ve AMAÇ: Bu çalışma, primer fibromiyalji sendromlu (FMS) hastaların klinik semptomlarının tedavisinde ve yaşam kalitesinin düzeltilmesinde düşük yoğunluklu lazer (DYL) tedavisinin etkinliğini araştırmak amaciyla planlandi.

YÖNTEM ve GEREÇLER: Primer FMS'lu 60 hasta, aktif gallium- arsenide (GaAs) lazer (30 hasta) ve plasebo lazer (30 hasta) olmak üzere rastgele iki gruba ayrıld. Tüm hastalar, hassas nokta sayısı, ağrı, sabah sertliği, uyku bozukluğu, yorgunluk, kas spazmı, subjektif şişlik hissi ve parestezilerdeki iyileşme oranı açısından değerlendirildi. Yaşam kalitesinin değerlendirilmesi ise fibromiyalji etki sorgulamasına (FIQ) göre yapıldı. Aktif lazer grubunda hastalara, her noktaya 2 dakika, $4,4 \mathrm{~J} / \mathrm{cm} 2 \mathrm{Ga}$-As lazer tedavisi 10 gün boyunca uygulandı. Plasebo tedavi için ise lazer ışını yayılmadan yine aynı cihaz kullanıldı. BULGULAR: Tedavi sonrasında tüm parametrelerde her iki grupta da istatiksel olarak anlamlı düzeyde iyileşme saptandi.

TARTIŞMA ve SONUÇ: Elde ettiğimiz sonuçlar, FMS nin tedavisinde DYL uygulanmasının etkili olduğunu ve etyopatogenezinde emosyonel faktörlerin önemli rol oynadığını düşündürmektedir.

Anahtar Kelimeler: Fibromiyalji, lazer tedavisi, placebo etkisi, tedavi.

\begin{abstract}
INTRODUCTION: This study investigates the efficiency of low level laser therapy (LLLT) in the treatment of clinical symptoms and improvement of the quality of life in patients diagnosed with primary fibromyalgia syndrome (FMS).

METHODS: Sixty primary FMS patients were randomly divided into two groups: active gallium-arsenide (GaAs) laser (30 patients) and placebo laser (30 patients). All the patients were assessed in terms of recovery rates in tender point quantity, pain, morning stiffness, sleep disorder, fatigue, muscle spasm, subjective swelling and paresthesia. Assessment of the quality of life was performed according to the fibromyalgia impact questionnaire (FIQ). Two minutes of $4,4 \mathrm{~J} / \mathrm{cm} 2 \mathrm{Ga}$-As laser therapy to every point was applied to the patients in the active laser group for 10 days. For placebo therapy, the application was applied for the same period of time without radiating any laser beams.
\end{abstract}

RESULTS: After the treatment, statistically significant recovery was observed in both groups in terms of all parameters.

DISCUSSION AND CONCLUSION: Our results suggest that application of LLLT is effective in the treatment of FMS and emotional factors may play an important role in its etiopathogenesis.

Keywords: Fibromyalgia, laser therapy, placebo effects, treatment

\section{INTRODUCTION}

Fibromyalgia syndrome (FMS) is a noninflammatory, non-autoimmune, extra articular rheumatic disease characterized by common pain in the body, fatigue, stiffness, sleep disorders, paresthesia and subjective swellings and tender points in specific areas in the body (1). Muscle strength tends to decrease in FMS. The etiology of FMS is still not exactly known, and there are no specific laboratory and 
radiological methods for diagnosing the disorder. Although training, exercises, and cognitive behavioral therapies are helpful for alleviating the symptoms of FMS, it is also important to eliminate pain increasing factors such as anxiety, depression, and poor posture (2).

Medical options for treating FMS that have been highlighted recently include tropisetron, tramadol, gabapentin, pregabalin, duloxetine, selective serotonin and norepinephrine reuptake inhibitors, exogenous melatonin, growth hormone and calcitonin (3). Other treatment methods are exercise, cardiovascular fitness training, biofeedback, hypnotherapy, cognitive behavioral therapy, massage, tender point injection and physical treatment modalities (e.g., transcutaneous electrical stimulation, acupuncture, interference, ultrasound, and laser treatments) (4).

A type of physical treatment modality, low level laser therapy (LLLT) is used in the treatment of various musculoskeletal system diseases due to its analgesic and antiinflammatory properties. It can be used also in the treatment of FMS and myofascial pain syndrome (MPS) (5). However, the results of placebo-controlled studies regarding the efficacy of laser treatment are controversial for FMS and MPS. Although in a group of study, it is notified that LLLT is more efficient than placebo $(6,7)$ another study group showed that there is no difference between LLLT and placebo treatments $(8,9,10)$. In the present study, we aim to investigate the effectiveness of placebo laser therapy and low-level laser therapy in patients diagnosed with FMS.

\section{METHODS}

Sixty female patients with an average age of 40 (30-56) who were diagnosed with primary FMS according to the diagnosis criteria (11) laid out by the American College of Rheumatology (ACR). Physical examinations were conducted to confirm an FMS diagnosis. The research was planned as placebo-controlled. After each patient provided written consent, subjects were randomly divided in two groups before beginning treatment in order to eliminate the presence of another clinical picture. Hemogram, biochemistry, sedimentation, serum reactive protein, rheumatoid factor, Brucella, and anti- nuclear antibody examinations of all the patients were conducted. All patients were asked about their age, level of education, marital status and duration of disease. When required, imaging methods were used to confirm a diagnosis of pain.

Exclusion criteria for the study's sample included the use of drug therapy or physical therapy for treating FMS in the last six months, chronic inflammatory disease, diabetes mellitus, major depressive disorder, alcohol or drug abuse and pregnancy.

Strength of the complaints of all the patients in both groups such as pain, morning stiffness, sleep disorder, fatigue, muscle spasms, subjective swelling and paresthesia were graded between 0 and 4 in a Likert type Scale with the following indications: 0 : none, 1 : mild, 2 : moderate, 3 : severe, and 4: intolerable $(6,12,13)$.

In order to determine the effect of FMS on patients' quality of life, a Fibromyalgia Impact Questionnaire (FIQ) form was used. The FIQ is a questionnaire form developed for FMS patients, which assesses elements such as physical functions, working, depression, anxiety, sleeping, pain, stiffness, fatigue and feeling good with a minimum value of 0 and a maximum value of $100(14,15)$.

For laser therapy, infrared $27 \mathrm{Ga}$-As laser device with a wavelength of $904 \mathrm{~nm}$ was used (Italian made ElettronicaPagani). During usage, the average power output of the device was adjusted as $7.2 \mathrm{~mW}$ with a frequency of 3000 $\mathrm{Hz}$ and an energy density per point of $4.4 \mathrm{~J} / \mathrm{cm} 2$. For ten continuous sessions, painful fibromyalgia tender points were treated with laser therapy. Each tender point was treated for two minutes via a full contact technique using a 90-degree, vertical angle. In the placebo group, application was performed using the same method with the same period and number of sessions, but the device was inactive. In all treatment sessions, patients' eyes were closed with an eye protecting material. All patients were informed during the study that they were not to take any other treating agents or drugs. Treatment applications and assessment of the treatment results of the patients were performed by two different doctors. The doctor assessing the treatment did not know the either group of patients.

The SPSS 11.5 statistical package program was used for statistical analysis. Demographic data was analyzed using 
definitive statistical methods. A chi-square test was used for the difference analyses of categorical variables from demographic data between the groups before treatment. For comparison of the before and after treatment measurements among the groups, either student's t or Mann-Whitney U tests were used according to the distributions. For the comparison of the ratio changes after the treatment between the groups, a student's $t$ test was applied when the distribution was normal and a Mann-Whitney U test was applied when the distribution was not normal. The level of significance for the statistical analysis was set at $5 \%(\mathrm{P} \leq 0.05)$.

\section{RESULTS}

Average age of laser and placebo groups was 39.4 \pm 7.1 and $40.7 \pm 7.3$ years, respectively. Duration of disease was $5.7 \pm 5.7$ in the laser group and 4.5 \pm 3.4 years in the placebo group. No statistically significant difference was observed between the treatment groups in terms of age and disease duration. (Table 1)

When Likert scale values of symptoms, total number of tender points and FIQ score values before treatment of both groups were compared, no statistically significant difference was observed in any of the parameters between both groups (Table 2) $(\mathrm{P}>0.05)$.

In both groups, when the Likert scale values of symptoms, number of total tender points, and FIQ score values after treatment were compared according to values before treatment, statistically significant recovery was observed (Table 3 ).

When the percentages of changes in parameters before and after treatment in both groups were compared, no statistical difference was observed between the groups.

Table 1. Age and disease periods of the treatment groups

\begin{tabular}{|l|l|l|l|} 
& $\begin{array}{l}\text { Laser } \\
\text { Group } \\
\mathrm{n}=30\end{array}$ & $\begin{array}{l}\text { Placebo Group } \\
\mathrm{n}=30\end{array}$ & $\mathrm{P}$ \\
\hline $\begin{array}{l}\text { Age } \\
\text { (years) }\end{array}$ & $\begin{array}{l}39.4+ \\
7.1\end{array}$ & $40.7+7.3$ & $>0.05^{*}$ \\
\hline $\begin{array}{l}\text { Disease } \\
\text { period } \\
\text { (years) }\end{array}$ & $5.7+$ & 5.7 & $>0.05^{*}$ \\
\hline
\end{tabular}

Table 2. Comparison of total Likert scale values, total number of tender points, and total
FIQ score values of both placebo and laser groups before treatment

\begin{tabular}{|c|c|c|c|}
\hline & $\begin{array}{l}\text { Before trea } \\
n=30\end{array}$ & ment & $\mathrm{P}$ \\
\hline & Laser G & $\begin{array}{l}\text { Placebo } \\
\text { G }\end{array}$ & \\
\hline $\begin{array}{l}\text { No. } \\
\text { tender } \\
\text { points }\end{array}$ & $13.4+2.4$ & $\begin{array}{l}13.1+ \\
1.9\end{array}$ & $>0.05 *$ \\
\hline $\begin{array}{l}\text { Pain } \\
\text { intensity }\end{array}$ & $2.6+0.8$ & $2.7+0.7$ & $>0.05^{*}$ \\
\hline Stiffness & $2+1.1$ & $1.9+0.8$ & $>0.05^{*}$ \\
\hline $\begin{array}{l}\text { Sleep } \\
\text { disorder }\end{array}$ & $1.6+1.1$ & $1.3+1.3$ & $>0.05^{*}$ \\
\hline Fatigue & $2.5+0.8$ & $2.6+1$ & $>0.05^{*}$ \\
\hline $\begin{array}{l}\text { Muscle } \\
\text { spasms }\end{array}$ & $1.9+1$ & $2.3+1.1$ & $>0.05^{*}$ \\
\hline $\begin{array}{l}\text { Subjective } \\
\text { swelling }\end{array}$ & $1.3+0.9$ & $1.3+1.1$ & $>0.05^{*}$ \\
\hline Paresthesia & $1.7+0.9$ & $1.3+0.9$ & $>0.05^{*}$ \\
\hline Total Likert & $13.5+3.9$ & $\begin{array}{l}13.3+ \\
3.9\end{array}$ & $>0.05 * *$ \\
\hline Total FIQ & $\begin{array}{l}54.6 \\
11.7\end{array}$ & $55.1+12$ & $>0.05 * *$ \\
\hline
\end{tabular}

*: Mann Whitney $\mathrm{U}, * *$ : student $\mathrm{t}, \mathrm{P}<0.05$ is accepted as significant

Table 3. Comparison of number of tender points, symptom strength levels and FIQ score values after treatment with the values before treatment in the placebo and laser group

\begin{tabular}{|c|c|c|c|c|c|c|}
\hline & \multicolumn{2}{|c|}{$\begin{array}{l}\text { Laser group } \\
n=30\end{array}$} & \multirow[t]{2}{*}{$\mathrm{P}$} & \multicolumn{2}{|c|}{$\begin{array}{l}\text { Placebo group } \\
n=30\end{array}$} & \multirow[t]{2}{*}{$\mathrm{P}$} \\
\hline & $\begin{array}{l}\text { Befor } \\
\mathrm{e} \\
\text { treat } \\
\text { ment }\end{array}$ & $\begin{array}{l}\text { After } \\
\text { treatm } \\
\text { ent }\end{array}$ & & $\begin{array}{l}\text { Befor } \\
\text { e } \\
\text { treat } \\
\text { ment }\end{array}$ & $\begin{array}{l}\text { After } \\
\text { treat } \\
\text { ment }\end{array}$ & \\
\hline $\begin{array}{l}\text { No. of } \\
\text { tender } \\
\text { points }\end{array}$ & $\begin{array}{l}13.4 \\
+2.4\end{array}$ & $7.1+4$ & $\begin{array}{l}<0 . \\
001 \\
*\end{array}$ & $\begin{array}{l}13.1 \\
+1.9\end{array}$ & $\begin{array}{l}7.6+ \\
3.8\end{array}$ & $\begin{array}{l}<0 . \\
001\end{array}$ \\
\hline $\begin{array}{l}\text { Pain } \\
\text { intensi } \\
\text { ty }\end{array}$ & $\begin{array}{l}2.6+ \\
0.8\end{array}$ & $\begin{array}{l}1.4 \\
0.6\end{array}+$ & $\begin{array}{l}<0 . \\
001 \\
*\end{array}$ & $\begin{array}{l}2.7+ \\
0.7\end{array}$ & $\begin{array}{l}1.6+ \\
0.7\end{array}$ & $\begin{array}{l}<0 . \\
001\end{array}$ \\
\hline $\begin{array}{l}\text { Stiffne } \\
\text { ss }\end{array}$ & $\begin{array}{l}2 \\
1.1\end{array}+$ & $1+1$ & $\begin{array}{l}<0 . \\
001 \\
*\end{array}$ & $\begin{array}{l}1.9+ \\
0.8\end{array}$ & $\begin{array}{l}1.1+ \\
0.8\end{array}$ & $\begin{array}{l}<0 . \\
001\end{array}$ \\
\hline $\begin{array}{l}\text { Sleep } \\
\text { disord } \\
\text { er }\end{array}$ & $\begin{array}{l}1.6+ \\
1.1\end{array}$ & $0.8+1$ & $\begin{array}{l}<0 . \\
001 \\
*\end{array}$ & $\begin{array}{l}1.3+ \\
1.3\end{array}$ & $\begin{array}{l}0.6+ \\
0.9\end{array}$ & $\begin{array}{l}<0 . \\
001\end{array}$ \\
\hline $\begin{array}{l}\text { Fatigu } \\
\mathrm{e}\end{array}$ & $\begin{array}{l}2.5+ \\
0.8\end{array}$ & $\begin{array}{l}1.4 \\
0.7\end{array}$ & $\begin{array}{l}<0 . \\
001 \\
*\end{array}$ & $\begin{array}{l}2.6+ \\
1\end{array}$ & $\begin{array}{l}1.3+ \\
0.9\end{array}$ & $\begin{array}{l}<0 . \\
001\end{array}$ \\
\hline $\begin{array}{l}\text { Muscl } \\
\text { e } \\
\text { spasm } \\
\text { s }\end{array}$ & $\begin{array}{l}1.9+ \\
1\end{array}$ & $\begin{array}{l}0.9 \\
0.9\end{array}$ & $\begin{array}{l}<0 . \\
001 \\
*\end{array}$ & $\begin{array}{l}2.3+ \\
1.1\end{array}$ & $\begin{array}{l}1.2+ \\
1.1\end{array}$ & $\begin{array}{l}<0 . \\
001\end{array}$ \\
\hline $\begin{array}{l}\text { Subjec } \\
\text { tive } \\
\text { swelli } \\
\text { ng }\end{array}$ & $\begin{array}{l}1.3+ \\
0.9\end{array}$ & $\begin{array}{l}0.6+ \\
0.7\end{array}$ & $\begin{array}{l}<0 . \\
001 \\
*\end{array}$ & $\begin{array}{l}1.3+ \\
1.1\end{array}$ & $\begin{array}{l}0.5+ \\
0.6\end{array}$ & $\begin{array}{l}<0 . \\
001\end{array}$ \\
\hline
\end{tabular}




\begin{tabular}{|c|c|c|c|c|c|c|}
\hline $\begin{array}{l}\text { Parest } \\
\text { hesia }\end{array}$ & $\begin{array}{l}1.7+ \\
0.9\end{array}$ & $\begin{array}{l}0.7 \\
0.5\end{array}+$ & $\begin{array}{l}<0 . \\
001 \\
*\end{array}$ & $\begin{array}{l}1.3+ \\
0.9\end{array}$ & $\begin{array}{l}0.7+ \\
0.8\end{array}$ & $\begin{array}{l}<0 . \\
001\end{array}$ \\
\hline $\begin{array}{l}\text { Total } \\
\text { Likert }\end{array}$ & $\begin{array}{l}13.5 \\
+3.9\end{array}$ & $\begin{array}{l}6.8+ \\
3.4\end{array}$ & $\begin{array}{l}<0 . \\
001 \\
* *\end{array}$ & $\begin{array}{l}13.3 \\
+3.9\end{array}$ & $\begin{array}{l}6.9+ \\
4.2\end{array}$ & $\begin{array}{l}<0 . \\
001\end{array}$ \\
\hline $\begin{array}{l}\text { Total } \\
\text { FIQ }\end{array}$ & $\begin{array}{l}54.6 \\
+ \\
11.7\end{array}$ & $\begin{array}{l}2.3 \\
12.3\end{array}+$ & $\begin{array}{l}<0 . \\
001 \\
* *\end{array}$ & $\begin{array}{l}55.6 \\
+12 . \\
5\end{array}$ & $\begin{array}{l}33.9 \\
+14 . \\
8\end{array}$ & $\begin{array}{l}<0 . \\
001\end{array}$ \\
\hline
\end{tabular}

*: Mann Whitney $\mathrm{U}$, **: student $\mathrm{t}$

\section{DISCUSSION}

Although various methods have been used to treat FMS, controlled, randomized, long-term studies regarding effective treatment of FMS are limited. The present study examines the use of laser therapy and utilizes controlled and randomized methods to illuminate knowledge regarding effective treatment of FMS. While medical treatments include side effects and the risk drug interaction (5), LLLT is a physical treatment modality that is non-invasive, easily applicable and has minimal side effects. The efficiency of LLLT in the treatment of various chronic pain conditions such as plantar fasciitis, carpal tunnel syndrome, lateral epicondylitis and osteoarthritis has been reported; however, the results are somewhat controversial. Although some studies claim laser therapy's ineffectiveness in treating medical conditions $(16,17)$, some studies demonstrate how laser therapy's analgesic effect is effective for treating various chronic pain conditions including MPS $(7,18,19)$. Though laser therapy has been shown to be effective in treating MPS, results of studies investigating the efficiency of LLLT in FMS treatment are controversial. For example, in a study made by Gür et al. that investigated the efficiency of LLLT on 40 FMS patients, researchers compared LLLT and lowdose amitriptyline treatment in FMS patients and found that both LLLT and amitriptyline treatment are efficient in reducing the clinical symptoms of FMS. While LLLT was superior to amitriptyline in terms of reducing pain intensity and fatigue, the two treatments were equally effective in all other parameters (12). However, the researchers do specify that significant recoveries were obtained in the laser group compared to the placebo group in terms of pain, muscle spasms, morning stiffness and number of tender points. They also found that laser therapy is more efficient for mitigating sleep disorders and reducing the number of total tender points when compared to placebo laser therapy. Thus, Gür et al. argue that laser therapy is an efficient and safe treatment option in fibromyalgia patients (6).

In a study conducted by Waylonis et al., researchers found no significant different in pain response and treatment efficiency between FMS patients treated with laser therapy and FMS patients treated with placebo laser therapy (19). Bingöl et al. investigated the efficacy of LLLT in treating FMS. They used an exercise program for the first group and a placebo laser and exercise program to the other group. They noted that laser therapy has no superiority over placebo treatments with regards to pain reduction (20). Moreover, Matsutaniet al. show that additional laser therapy has no benefit for FMS patients who have participated in an exercise program (8). Vayvay et al. divided fibromyalgia patients into three random groups and applied laser therapy to one group, placebo laser therapy to another group and kinesiotaping to the last group. They assessed the responses of the patients to the treatments after three weeks and did not observed any significant differences between treatment groups (21). However, a central problem in comparing results across the literature is the variability of parameters such as wavelength, power output and pulsation frequency and the incorporation of nonstandard treatment regimes.

It has been reported that the analgesic and biostimulating effect of LLLT increases both the peak level of pain and the local concentration of serotonin and endorphins (22). In another study, it is specified that laser therapy reduces prostaglandin (PG) synthesis and has an anti-inflammatory and an anti-edematous effect (23).

In some studies related to FMS, efficient results of placebo treatments suggest that there is a significant emotional dimension in the etiopathogenesis of FMS $(24,25)$. Before starting treatment, our patients were informed about their disease and the treatment to be applied. This increased their conformance to the treatment. Continuous treatment and reliance of patients on their doctors also contributed to increased treatment conformance. Patients overcoming their fear of FMS, which can result from having a good relationship with a doctor, could be a reason why the same efficacy was observed in both the active treatment and placebo groups. In our study, recovery in all assessment parameters of laser therapy 
compared to values before treatment comply with various studies that defend the efficiency of laser therapy in treating FMS $(6,7,12)$. We suggest that further studies on this topic be conducted using different laser types and dosages in larger patient populations.

In conclusion, LLLT is an efficient method in the treatment of FMS patients that is easily applicable and involves less side effects, similar recovery levels in the placebo group reveals that emotional factors have an important role in the experience and amelioration of the disease. Thus, this dimension should not be ignored in the research and treatment of FMS.

\section{Declaration of conflicting interests}

The authors declared no conflicts of interest with respect to the authorship and/or publication of this article.

\section{REFERENCES}

1- Wilson HD, Robinson JP, Turk DC. Toward the identification of symptom patterns in people with fibromyalgia. Arthritis Rheum. 2009;61:527-34.

2- Burckhardt CS. Multidisciplinary approaches for management of fibromyalgia. Curr Pharm Des. 2006;12:59-66.

3- Calandre EP, Rica-Villademoros F, Slim M. An update on pharmacotherapy for the treatment of ibromyalgia.Expert Opin Pharmacother. 2015;16:1347-68.

4- Cassisi G, Ceccherelli F, Atzeni F, Sarzi-Puttini P. Complementary and alternative medicine in fibromyalgia: a practical clinical debate of agreements and contrasts. Clin Exp Rheumatol. 2013;31:134-52

5- Gur A. Physical therapy modalities in management of fibromyalgia. Curr Pharm Des. 2006; 12:29-35.

6- Gür A, Karakoç M, Nas K, Cevik R, Sarac J, Ataoğlu S. Efficacy of low power laser therapy in fibromyalgia: a single blind plesebocontrolled trial. Lasers Med Sci. 2002;17: 57-61.

7- Ruaro JA, FrezAr, Ruaro MB, Nicolau RA. Low-level laser therapy to treat fibromyalgia. Lasers Med Sci. 2014; 29:1815-9.

8- Matsutani LA, Marques AP, Ferreira EA, Assumpção A, Lage LV, Casarotto RA, et al. Effectiveness of muscle stretching exercises with and without laser therapy at tender points for patients with fibromyalgia. Clin Exp Rheumatol. 2007; 25:410-5.

9- Manca A, Limonta E, Pilurzi G, Ginatempo F, De Natale ER, Mercante B, et al. Ultrasound and laser as stand-alone therapies for myofascial trigger points: a rando, double, placebocontrolled study. Physiother Res Int. 2014;19:166-75.
10- Amanat D, Ebrahimi H, Lavaee F, Alipour A. The adjunct therapeutic effect of lasers with madication in the management of orofacial pain: double blind randomized contralled trial. Photomed Laser Surg. 2013;31:474-9.

11- Wolfe F, Smythe HA, Yunus MB, Bennet RM, Bombardier C, Goldenberg DL, et al. The American College of Rheumatology 1990 Criteria for the classification of fibromyalgia. Arthritis Rheum. 1990;33:160-72.

12- Gür A, Karakoc M, Nas K, Cevik R, Sarac J, Ataoğlu S. Effects of low power laser and low dose amitriptyline therapy on clinical symtoms and quality of life in fibromyalgia : a single blind placebo-controlled trial. Rheumatol Int. 2002;22: 188-93.

13- Bellamy, N. and Buchanan, W. T. Clinical evaluation in the rheumatic diseases. In William J. Koopman and Larry W. Moreland (Ed.), Arthritis and Allied Conditions 15th ed.Philadelphia, U.S.A.: Lippincott Williams \& Wilkins; 2005. p. 51-80.

14- Sarmer S, Ergin S, Yavuzer G. The validity and reliability of the Turkish version of the Fibromyalgia Impact Questionare. Rheumatol Int. 2000;20:9-12.

15- Burckhardt CS, Clark SR, Bennet RM. The fibromyalgia impact questionnaire: development and validation. J Rheumatol. 1991;18:728-33.

16- Ay S, Doğan SK, Evcik D. Is low-level laser therapy effective in acute or chronic low back pain? Clin Rheumatol. 2010;29:905-10.

17- Emanet SK, Altan LI, Yurtkuran M. Investigation of the effect of GaAs laser therapy on lateral epicondilitis. Photomed Laser Surg. 2010;28:397-403.

18- Hakgüder A, Birtane M, Gürcan S, Kokino S, Turan FM. Efficacy of low level laser therapy in myofascial pain syndrome: an algometric and thermographic evaluation. Lasers Surg Med. 2003;33:339-43.

19- Waylonis GW, Wilke S, O'toole D, Waylonis DA, Waylonis DB. Chronic myofascial pain: management by low-output helium laser therapy. Arch Phys Med Rehabil. 1988;69;101720.

20- Bingöl U, Altan L, Yurtkuran M. Low-power laser therapy for shoulder pain. Photomed Laser Surg. 2005;23:459-64.

21- Vayvav ES, Tok D, Turgut E, Tunay VB. The effect of Laser and taping on pain, functional status and quality of life in patients with fibromyalgia syndrome: A placeborandomized controlled clinical trial. J Back Musculoskelet Rehabil. 2016;29:77-83.

22- Tam G. Low power laser therapy and analgesic action. J Clin Laser Med Surg. 1999;17:29-33.

23- Barberis G, Gamron S, Acevedo G, Cadile I, Juri $\mathrm{H}$, Campana V, et al. In vitro synthesis of prostoglandin E2 by synovial tissue after helium-neon laser radiation in rheumatoid arthritis. J Clin Laser Med Surg. 1996;14:175-7.

24- Salgueiro M, Aira Z, Buesa I, Bilbao J, Azkue JJ. Is psychological distress intrinsic to 
fibromyalgia syndrome? Cross-sectional analysis in two clinical presentations. Rheumatol Int. 2012;32:3463-9.

25- Alok R, Das SK, Agarwal GG, Salwahan L, Srivastava R. Relationship of severity of depression, anxiety and stress with severity of fibromyalgia. Clin Exp Rheumatol. 2011;29:702. 